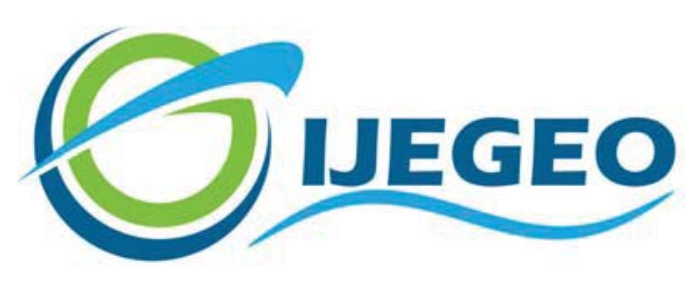

International Journal of Environment and Geoinformatics (IJEGEO) is an international, multidisciplinary, peer reviewed, open access journal.

\title{
Archeological Traces of Sixth Century Earthquakes in İstanbul Küçükçekmece Lake Basin (Bathonea) Excavations
}

\section{Şerif BARIŞ, Şengül AYDINGÜN, Hakan KAYA, Cem GAZİOĞLU}

\author{
Chief in Editor \\ Prof. Dr. Cem Gazioğlu \\ Co-Editors \\ Prof. Dr. Dursun Zafer Şeker, Prof. Dr. Şinasi Kaya, \\ Prof. Dr. Ayşegül Tanık and Assist. Prof. Dr. Volkan Demir
}

Editorial Committee (September 2021)

Assoc. Prof. Dr. Abdullah Aksu (TR), Assit. Prof. Dr. Uğur Algancı (TR), Prof. Dr. Bedri Alpar (TR), Assoc. Prof. Dr. Aslı Aslan (US), Prof. Dr. Levent Bat (TR), Prof. Dr. Paul Bates (UK), İrşad Bayırhan (TR), Prof. Dr. Bülent Bayram (TR), Prof. Dr. Luis M. Botana (ES), Prof. Dr. Nuray Çağlar (TR), Prof. Dr. Sukanta Dash (IN), Dr. Soofia T. Elias (UK), Prof. Dr. A. Evren Erginal (TR), Assoc. Prof. Dr. Cüneyt Erenoğlu (TR), Dr. Dieter Fritsch (DE), Prof. Dr. Çiğdem Göksel (TR), Prof.Dr. Lena Halounova (CZ), Prof. Dr. Manik Kalubarme (IN), Dr. Hakan Kaya (TR), Assist. Prof. Dr. Serkan Kükrer (TR), Assoc. Prof. Dr. Maged Marghany (MY), Prof. Dr. Michael Meadows (ZA), Prof. Dr. Nebiye Musaoğlu (TR), Prof. Dr. Masafumi Nakagawa (JP), Prof. Dr. Hasan Özdemir (TR), Prof. Dr. Chryssy Potsiou (GR), Prof. Dr. Erol Sarı (TR), Prof. Dr. Maria Paradiso (IT), Prof. Dr. Petros Patias (GR), Prof. Dr. Elif Sertel (TR), Prof. Dr. Nüket Sivri (TR), Prof. Dr. Füsun Balık Şanlı (TR), Prof. Dr. Uğur Şanlı (TR), Duygu Ülker (TR), Prof. Dr. Seyfettin Taş (TR), Assoc. Prof. Dr. Ömer Suat Taşkın (TR), Assist. Prof. Dr. Tuba Ünsal (TR), Dr. Manousos Valyrakis (UK), Dr. İnese Varna (LV), Dr. Petra Visser (NL), Prof. Dr. Selma Ünlü (TR), Assoc. Prof. Dr. Oral Yağcı (TR), Prof. Dr. Murat Yakar (TR), Assoc. Prof. Dr. İ. Noyan Y1lmaz (AU); Assit. Prof. Dr. Sibel Zeki (TR) 


\title{
Archeological Traces of Sixth Century Earthquakes in İstanbul Küçükçekmece Lake Basin (Bathonea) Excavations
}

\author{
Şerif Barış̧ ${ }^{1, *}$ (iD) , Şengül Aydıngün ${ }^{2}$ (i) , Hakan Kaya ${ }^{3}$,D Cem Gazioğlu ${ }^{3,4}$ (D) \\ ${ }^{1}$ Department of Geophysics, Faculty of Engineering, Kocaeli University, TR \\ ${ }^{2}$ Department of Archaeology, Faculty of Art and Science, Kocaeli University, TR \\ ${ }^{3}$ Istanbul University, Institute of Marine Sciences and Management, Department of Marine Environment, 34134 Vefa Istanbul TR \\ ${ }^{4}$ Istanbul University, Faculty of Architecture, Department of Architecture, 34126 Beyazit Istanbul TR
}

* Corresponding Author: Ş. Barış

Received: 21.04 .2020 E-mail:srfbrs@gmail.com

How to cite: Barış et al., (2021). Archeological Traces of Sixth Century Earthquakes in İstanbul Küçükçekmece Lake Basin (Bathonea) Excavations, International Journal of Environment and Geoinformatics (IJEGEO), 8(3):386-396, doi. 10.30897/ijegeo.914055

\begin{abstract}
Located $20 \mathrm{~km}$ west of the Bosporus, the Bathonea ancient port settlement on the Avc1lar / Firuzköy Peninsula northwest of Küçükçekmece Lagoon Lake has been the subject of archeological excavations with a multidisciplinary team since 2010. Excavations determined two separate structures with intense and destructive damage and studies were performed about whether or not this damage was caused by destructive earthquakes in the region. A church structure with an apse had most pronounced intense damage and skeletons belonging to two hugging individuals were identified under the stones of a collapsed dome. Additionally, coins dated to 550 and other archeological materials reveal the destructive earthquake occurred after 550 in the period of the Emperor Justinian (527-565). If it had occurred during the reign of a different emperor, the coins would have been out of circulation. Strong destructive traces were identified in other structures spread over a large area in the excavation site, apart from the apse structure. In the north of the peninsula nearly $600 \mathrm{~m}$ from the church structure, visible offsets and collapsed walls were revealed in the walls of a great water cistern. Deformation offsets and fractures observed in this cistern and in tunnels bringing water to the cistern provide evidence of earthquakes in the $6^{\text {th }}$ century. After the structure became unusable, bricks and stones used for construction of other structures in the $7-8^{\text {th }}$ centuries provide important data to date the earthquake. Excavations supporting geophysical studies continue. The results from the excavation confirm some historical earthquakes occurring in Istanbul and mentioned by ancient and medieval writers with archeological evidence for the first time.
\end{abstract}

Keywords: Küçükçekmece Lake, Avcılar, Firuzköy, Bathonea, Earthquake

\section{Introduction}

Archeological excavations have been completed by a multidisciplinary team since 2010 in the Avcılar/Firuzköy Peninsula northwest of Küçükçekmece Lagoon Lake $20 \mathrm{~km}$ west of the Bosporus ${ }^{1}$.

The Firuzköy Peninsula (Figure 1) was used by the first human communities in the Lower Paleolithic Period $(400,000)$ as understood from stone tools. From the PrePottery Neolithic to the Chalcolithic and Bronze ages (7000 - $1500 \mathrm{BC})$, the peninsula was discontinuously used for settlement as identified in drilling excavations. After being abandoned, Firuzköy Peninsula was revitalized in the Hellenistic period and had public structures built. In this period, coasts of the peninsula were surrounded by terrace walls and ports with docks and piers and roads were constructed. It is thought that there was a wider channel link between Küçükçekmece

\footnotetext{
${ }^{1}$ Based on Republic of Turkey Presidential Decree dated 14.07.2009 and numbered 15289, Assoc. Prof. Dr. Şengül Aydingün headed the excavations completed in the name of the Ministry for Culture and Tourism and Kocaeli University.
}

with the Sea of Marmara in the past then at present due to the presence of a lighthouse within the lagoon. Archeological findings show a protected internal pier was used in the region for sailors entering the Küçükçekmece Lagoon by passing through the Menekşe channel, called Mrymex in ancient times. According to ancient period writers, the name for the region was Bathynias / Bathonea due to the ancient Bathynias (Sazlidere) River entering the lake from the north (Aydıngün, 2017). The name for the region may have changed after the ancient period and it is considered to have been within the region identified as Rhegion after the $5^{\text {th }}$ century (Kaya et al., 2002; Aydıngün, 2017).

In the excavation area (Bathonea) located on the Firuzköy Peninsula within the Küçükçekmece Lagoon Lake, excavations were completed simultaneously in 3 different regions (great port region, small port region and structures within the walls) In these regions, structural remains from the Late Antiquity Period were mainly revealed.

A large planned structure with basilica, Matryrion, which may have been a palace-monastery complex and the presence of a large cistern structure revealed by 
excavations inside the wall system show this area, was planned as a special settlement. It is understood that there was special interest in Küçükçekmece during the period of Emperor Constantine I (306-337 / 8) and public structures were built. As is known, while Rome's great Emperor Constantine made Byzantium city state his capital, major development activities occurred in the center of the city and surroundings. Constantine personally prepared one of the largest urban development plans in history and transformed the city into a worksite for a seven-year period from AD 330 to
AD 337, constructing many buildings, new roads, aqueducts and cisterns, walls and ports. After the death of the emperor, other emperors continued development activities in the capital and surroundings. The Late Antiquity writer Ammianus Marcellinus (Rerum Gestarum, XXXI.1.1) cites that Valens constructed summer palaces in the close surroundings of the capital. An important road map of the Roman period, Tabula Peutingeriana, locates a center called Regio 12 miles from the capital.

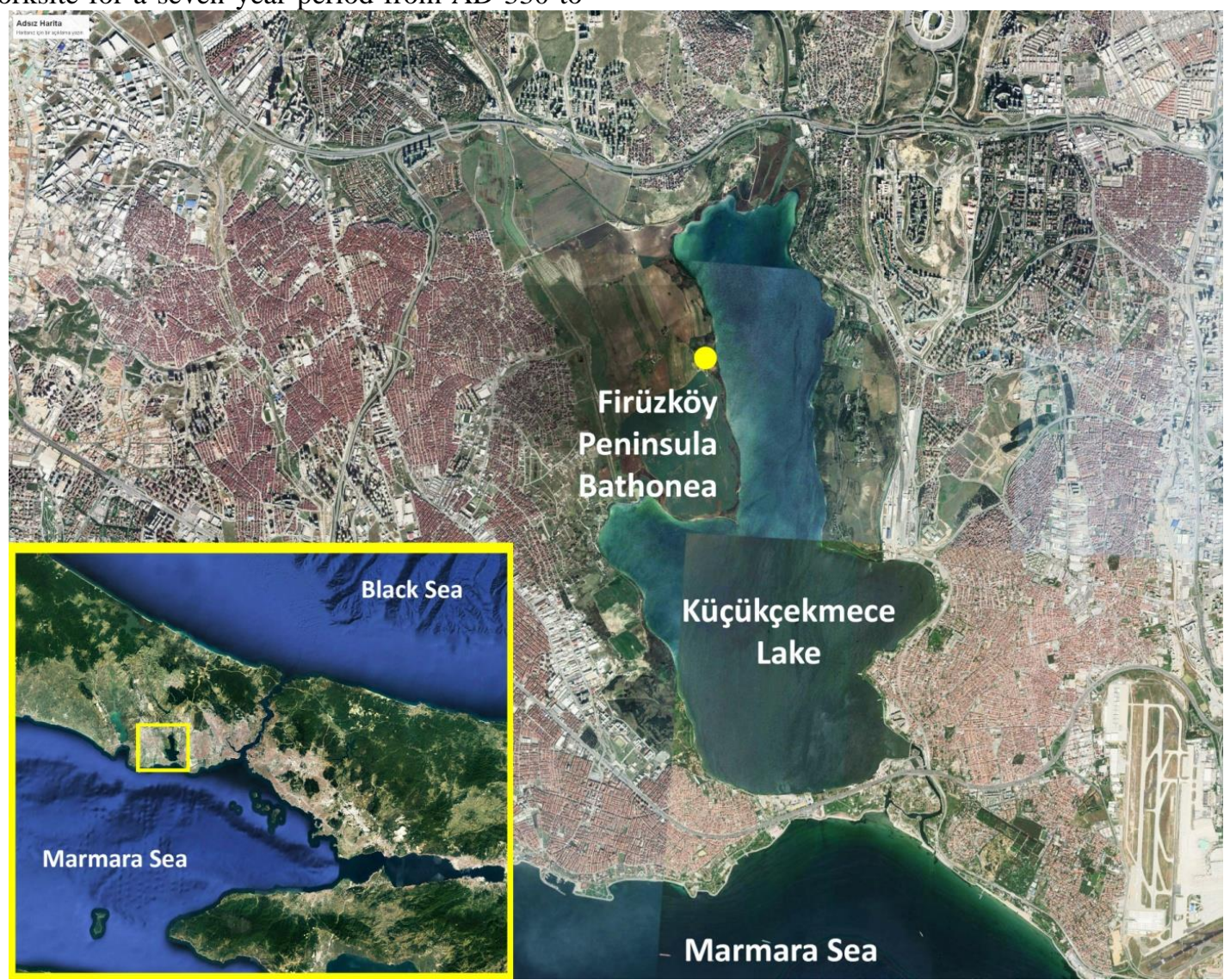

Fig. 1. İstanbul Küçükçekmece Lake basin - Avcılar-Firuzköy Peninsula (Google Earth, 2021).

Later the Emperor Theodosius is known to have contributed to construction in Küçükçekmece and surroundings. However, we learn that the fate of the region changed in written sources after a series of seismic events from the $6^{\text {th }}$ century. Accepted to have lived from AD 536-583, Agathias from Myrina in a book explaining events of the Justinian period from AD 552558 reported Rhegion was one of Istanbul's ports, an anchor site (Agathias 1828/1878). Living from AD 752818 , Theophanes mentioned the "events of 6050 year (AD 602-813)" and reported that severe earthquakes occurring in Istanbul in years equivalent to AD 557-558 collapsed the dome of Hagia Sophia and destroyed walls and churches. The most damage occurred in Rhegion (Küçükçekmece) and it was stated that it was razed to the ground and unrecognizable (Turtledove, 1982; Kaya et al., 2020).

\section{Tectonic Setting and Historical Earthquake Activity}

Istanbul metropolis where Bathonea Port was located is included in one of the world's most active earthquake belts of the Alpine-Himalayan belt. The fault zone producing the most significant earthquakes in this belt is the North Anatolian Fault Zone beginning in Karliova in the east and extending $1500 \mathrm{~km}$ to Greece in the Northern Aegean after passing within $10 \mathrm{~km}$ at closest and $20 \mathrm{~km}$ at most distant of the Istanbul coast (Ketin, 1948; Şengör, 1979; Barka, 1981; Emre et al., 2013; (Gazioğlu et al., 2002, Gökaşan et al., 2003; Hébert, e t al., 2005). This belt has produced large earthquakes for thousands of years and structures without earthquake resistance have experienced great destruction as a result of these earthquakes (Kartal and Kadirioğlu, 2015; Öniz et al., 2015). Some of the large earthquakes produced by this belt active for thousands of years are included in historical earthquake catalogues of destructive earthquakes, in history books and earthquakes close to the study area along the north branch in the last century include the 1912 Mürefte, 1963 Çınarcık, 1999 Kocaeli and 1999 Düzce earthquakes (URL 1).

Earthquakes occurring in the Marmara region and affecting Istanbul in the historical period and with 
intensity IX and above were reviewed by Korkusuz Öztürk and the map from this review is given in Figure 2.

Historical records show Istanbul has been affected by hundreds of earthquakes in the last two thousand five hundred years (Pınar and Lahn, 1959; Soysal et al., 1981; Tan et al., 2018) and it is said to have been destroyed tens of times due to large earthquakes in some periods (Bardakç1, 2015; Afyoncu, 2018). Our aim in this study is to illuminate the damage and remains caused due to large earthquakes occurring in the $6^{\text {th }}$ century as a result of findings obtained during excavations in the Bathonea excavation area.

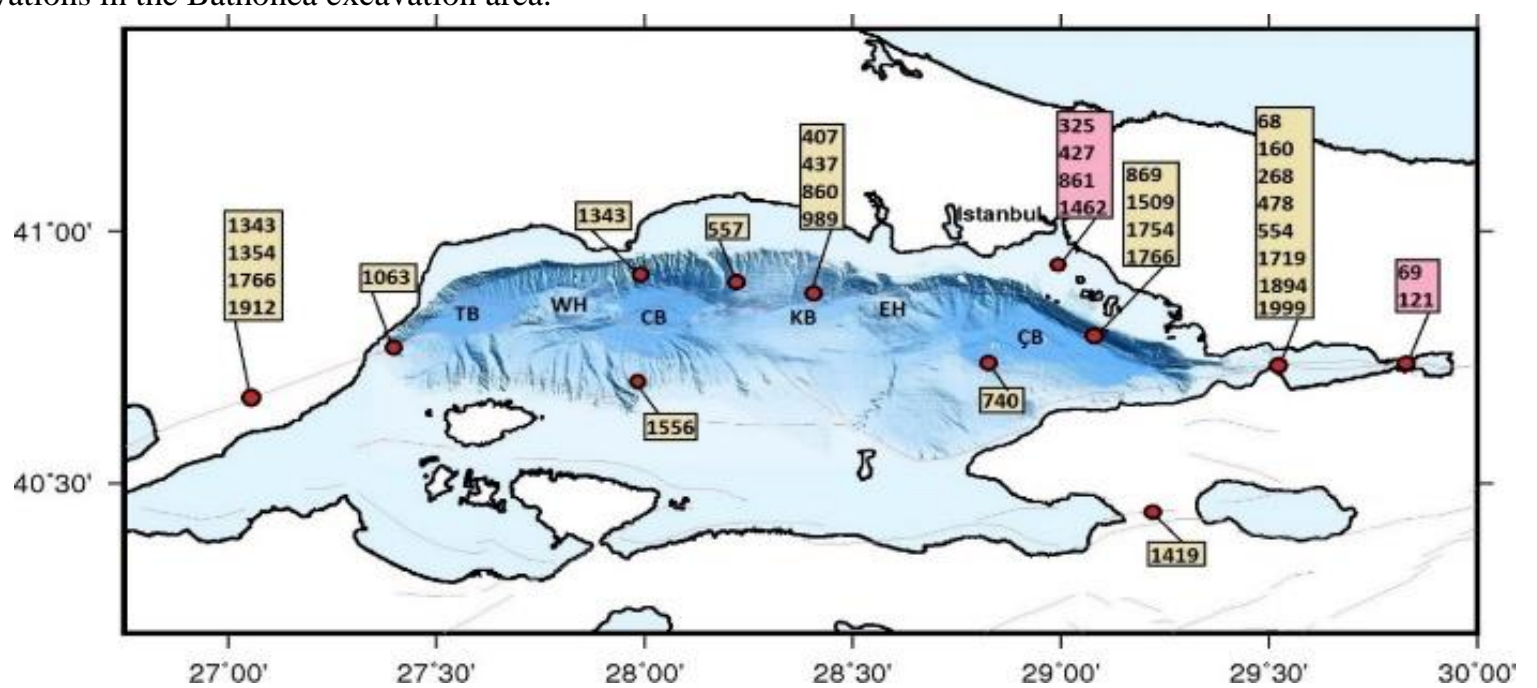

Fig. 2. Historical earthquakes occurring in the Marmara Region. Red circles show possible epicenters of earthquakes. Yellow boxes are dates according to Ambraseys 2002; Pink boxes give dates of earthquakes taken from Soysal et al., 1981; Guidoboni et al. 1994; Ambraseys, 2002; Ambraseys, 2009. Map taken from Korkusuz Öztürk, 2019.

This study confirms destruction caused by earthquakes in the region with a variety of archeological finds like collapses observed in the ancient city, destructions, fractures in monuments, collapses and displacement, bones of hugging individuals, deformation of skulls in these finds and irregular grave structures. There are many publications reviewing earthquakes occurring in Istanbul and surroundings and damaging the city. However, when detailed investigation is performed, some earthquakes were recorded repeatedly or an earthquake in one record is not included in another or there are differences observed in the intensity of these earthquakes (Başarır Baştürk et al., 2017).

In this way, an important difference in our study is worth mentioning here. Earthquakes said to affect Istanbul in the year 550 were included with intensity $\mathrm{V}$ in many historical earthquake catalogues (Soysal et al., 1997; Başarır Baştürk et al., 2017), while this earthquake was given moment instrumental magnitude $(\mathrm{Mw})$ of 7.30 in the publication by Tan et al. (2018), referencing Kondorskaya and Ulomov (1999).

Earthquakes written as occurring in this year are not included in publications by some historians (Boğaziçi University Kandilli Observatory Website, Bardakçı, 2015; Afyoncu, 2018). Considering the instrumental magnitude-intensity transformation in other catalogues, this value is equivalent to at least IX intensity and an
As a result, this study will only deal with earthquakes in this period to compare findings with earthquakes which occurred. As mentioned above, collapses and wall destruction revealed in excavations of Bathonea Ancient Port settlement and findings explained in following sections show that the city received significant damage as a result of large earthquakes. These explanations have generally been included in records written by historians; however, definite findings confirming this destruction, especially proof about earthquakes one thousand five hundred years ago, have not been obtained. 
earthquakes in catalogues significantly increases the number of earthquakes occurring in Istanbul. Writing by researchers who are not seismology experts indicate Istanbul was shaken by more than five hundred earthquakes in the last two thousand years (Afyoncu, 2018). Defining this type of earthquake identified as a very strong shock with $\mathrm{V}$ intensity on the Modified Mercalli Intensity Scale indicates people standing will feel the earthquake and that plates and bowls will break. An earthquake of this intensity is not predicted to cause damage to structures (Durukal et al., 2001; USGS, 2020). As earthquakes causing damage to several structures are earthquakes with intensity VII and above, this study accepted damaging earthquakes as those with this intensity or higher intensity. Additionally, earthquakes with lower intensity occurring in the same region or close surroundings within two years after a large earthquake were accepted as aftershocks. This study did not assess earthquakes with intensity V-VI or higher occurring within two years of a larger earthquake as earthquakes damaging the Bathonea settlement. Similarly, assessment included earthquakes with intensity VII and above in the historical catalogue as earthquakes affecting Bathonea.

Table gives all $6^{\text {th }}$ century earthquakes affecting Bathonea; however, earthquakes in bold font are qualified as damaging earthquakes. It appears only 2 different earthquakes had intensity that could damage the ancient city.

Evidence and sentences describing severe damage caused to Bathonea by these two earthquakes are explained in this section.

553 Earthquake: One earthquake causing intense damage and fear in Istanbul in the $6^{\text {th }}$ century occurred on 15 August 553 and was rumored to last 40 days according to historical references. One year after this earthquake, a range of earthquakes continuing through the summer months were qualified as strong aftershocks and were stated to cause damage in the city like collapse of many buildings and a church like the main shock. There is information that some of these collapsed structures were churches and the Yedikule dungeons and it was described that this earthquake caused a tsunami which flooded the internal sections of the city. According to Aydıngün (2005), the east arch of Hagia Sophia was damaged as a result of this earthquake and it fractured in an earthquake three years later due to weakened load-bearing strength.

This earthquake was also identified to cause intense damage in İzmit (Bitiren, https://listelist.com/tarihteistanbul-depremleri); (Pınar and Lahn, 1952; Bardakç1, 2015; Başarır Baştürk et al., 2018). This earthquake is recorded as intensity $\mathrm{X}$ in records, though some records state this earthquake occurred in 554 (Ambraseys, 2009; Başarır Baştürk et al., 2018). In the explanation section of Table 1, this earthquake was stated to have occurred in 555 with intensity $\mathrm{V}$ and VII. An intensity X earthquake would probably have instrumental magnitude calculated as 7.2 or larger and it is very normal for aftershocks to last two years after this type of earthquake (Barış, 1995). Some records contain information about an earthquake in 555 near Istanbul with instrumental magnitude 7.5, showing USGS records as reference (Sezer, 2003). However, this record was not included in this way on the historical earthquake websites or other catalogues of AFAD or Kandilli Observatory and Earthquake Research Institute. Başarır Baştürk et al., 2018; give three different references belonging to this earthquake and one of the references explained that this earthquake occurred in the region, but did not cause damage. The third reference showed this earthquake as intensity V. Many publications concluded that this earthquake did not have the intensity to reach the magnitude published by Sezer, and that this earthquake was probably an aftershock linked to the 553-554 earthquakes. Yaltırak (2015) stated this earthquake occurred in 553 with epicenter in the Gulf of İmit. Utkucu et al., 2011; stated that this earthquake occurred on 16 August 554, with earthquake epicenter at $40.70 \mathrm{~N}$ latitude and 29.80 E longitude in İzmit, and had instrumental magnitude of 6.9 (Ms).

557 Earthquake: Three different earthquakes are found in historical records in the year 557. Different references state the 16 October 557 earthquake had intensity IX (Ambraseys, 2009). Soysal et al., 1981; published that the intensity of the second earthquake in 557 was VIII. However, some publications state intense damage was caused by the earthquake on 14 December 557. According to Yaltırak (2015), the date of this earthquake was 23 December and this was defined as the largest earthquake with recurrence interval of 500 years (476 \pm 44 years) in the Marmara region and that the fault length was nearly $400 \mathrm{~km}$. Utkucu et al., 2011; dated this earthquake to 14 December 557 in their publication with epicenter coordinates $40.90 \mathrm{~N}$ latitude, $28.30 \mathrm{E}$ longitude, centered in the sea off Silivri with calculated instrumental magnitude 6.9 (Ms). With fuzzy analysis and other analyses, Korkusuz Öztürk, 2019, published the finding that this earthquake occurred off shore of Silivri and Tekirdağ.

This earthquake began with noises from underground and was accompanied by stormy weather, with information in historical records that the intensity of this earthquake was even recorded by the stars (Bardakç1, 2015). According to Afyoncu, the earthquake on 5 May 558 after the 557 earthquake collapsed the dome of Hagia Sophia and caused intense damage in Istanbul destroying hundreds of houses. According to Guidoboni et al., 1994; the intensity of this earthquake is accepted as X. Again, according to Ambraseys (2009), there is even information that this earthquake caused intense damage in Edirne. There is information that the city walls were damaged as a result of this earthquake, the hippodrome was destroyed and many churches and buildings were razed to the ground. In Istanbul, houses and churches in Bakırköy were even destroyed, with very large damage west of Küçükçekmece with no single house left standing (Ambraseys, 2009; Başarır Baştürk et al., 2018). It is normal that these earthquakes were probably followed by strong aftershocks in the region and that some catalogues will show these aftershocks as 
different earthquakes. These events are accepted as aftershocks and are ignored in this study. However, according to other references, the dome of Hagia Sophia collapsed in an earthquake occurring in 557 Aydıngün (2005) indicated that the effect of the earthquake in 557 displayed its effects 1 year later in 558 based on the Byzantine period historian Procopius and that the large arch on the east side of this magnificent structure, the semi-dome on the same side, and a large section of the main dome collapsed (Aydıngün 2005).

Table 1. Earthquakes occurring in the VI century affecting Bathonea ancient port settlement (URL.2.).

\begin{tabular}{|c|c|c|c|c|c|}
\hline & Latitude & Longitude & Location & Magnitude & Date \\
\hline 517 & 41.00 & 29.00 & Istanbul & VII & \\
\hline 4 October 525 & 41.00 & 29.00 & Istanbul & VI & \\
\hline 526 & 41.00 & 29.00 & Istanbul & VII & $\begin{array}{l}\text { May be the same as } 527 \\
\text { Istanbul earthquake }\end{array}$ \\
\hline 527 & 41.00 & 29.00 & Istanbul & VII & $\begin{array}{l}\text { May be the same as } 526 \\
\text { Istanbul earthquake }\end{array}$ \\
\hline November 533 & 41.00 & 29.00 & Istanbul & VII & $\mathrm{I}=\mathrm{V}(8) ;$ November $530(15)$ \\
\hline 16 August 541 & 41.00 & 29.00 & Istanbul & VIII & 16 August 542(8.1),541(2) \\
\hline November 545 & 41.00 & 29.00 & Istanbul & VI & $\mathrm{I}=\mathrm{V}(8)$ \\
\hline 546 & 41.00 & 29.00 & Istanbul & VII & $\begin{array}{c}\mathrm{I}=\mathrm{VI}(8), \text { may be the same as } \\
\text { November } 545 \text { Istanbul } \\
\text { earthquake }\end{array}$ \\
\hline 547 & 41.00 & 29.00 & Istanbul & $\mathrm{V}$ & $\begin{array}{l}\text { May be the same as } \\
\text { February } 548 \text { Istanbul } \\
\text { earthquake }\end{array}$ \\
\hline February 548 & 41.00 & 29.00 & Istanbul & $\mathrm{V}$ & - \\
\hline 549 & 41.00 & 29.00 & Istanbul & $\mathrm{V}$ & $\begin{array}{l}\text { May be the same as } 550 \\
\text { Istanbul earthquake }\end{array}$ \\
\hline 550 & 41.00 & 29.00 & Istanbul & V & - \\
\hline 15 August 553 & 41.00 & 29.00 & Istanbul Kocaeli & $\mathrm{X}$ & $\begin{array}{c}15 \text { Aug 551(9), } 11 \text { Jul } \\
554(9), 554(2), 16 \text { Aug } \\
554(8), \text { Io=5 andVII }(8), \\
555(11), 15 \text { Aug 555(8,2), } \\
16 \text { Aug 555(2) }\end{array}$ \\
\hline 2 April 557 & 41.00 & 29.00 & Istanbul & VIII & $558(9,12)$ \\
\hline 16 October 557 & 41.00 & 29.00 & Istanbul & VIII & $\begin{array}{c}06 \text { October } 557(1), \\
06 \text { October } 558(9), \\
\text { Io=IX }(1)\end{array}$ \\
\hline 14 December 557 & 41.00 & 29.00 & $\begin{array}{l}\text { Istanbul and } \\
\text { surroundings }\end{array}$ & VIII & $\begin{array}{l}14 \text { Nov } 557(8), 04 \mathrm{Dec} \\
558(9), 14 \operatorname{Dec} 558(2), \\
\text { Io=VII( } 8)\end{array}$ \\
\hline 559 & 41.00 & 29.00 & Istanbul & VI & - \\
\hline 560 & 41.00 & 29.00 & Istanbul & VI & - \\
\hline 580 & 41.00 & 29.00 & Istanbul & VI & - \\
\hline 582 & 41.00 & 29.00 & Istanbul & VI & - \\
\hline 10 May 583 & 41.00 & 29.00 & Istanbul & VII & - \\
\hline
\end{tabular}

*(References in explanations and in parentheses show references for historical data on the same page).

\section{Materials and Methods}

In addition to material obtained in archeological studies, this study assesses the multidisciplinary results of architectural and geophysical studies.

\section{Archeological Studies}

Apse Church: Excavations in Küçükçekmece Lake Basin (Bathonea) show that the apse church structure excavated in areas numbered 24-25 in the basin experienced a sudden collapse and was destroyed to the foundations based on architectural remnants (Figure 3ab). Additionally, an important example proving this situation was the identification of the skeletons of two individuals, holding each other, under the dome stones and rubble in the structure. Probably praying in this church, these people could not escape from sudden and very intense shaking (due to seismic movements) and 
held each other in fear before losing their lives under the dome stones falling from above.

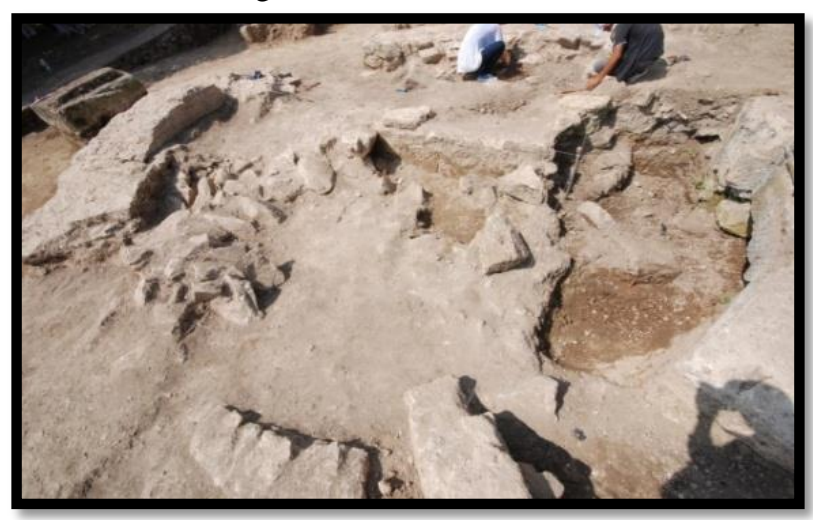

Fig 3a. Excavation of collapsed semi-dome of church.

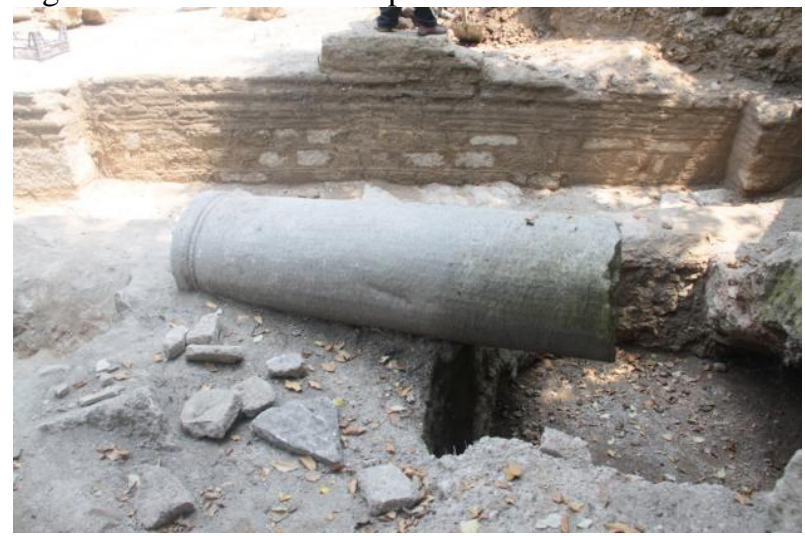

Fig. 3b. Sudden collapse and destroyed architectural remnants.
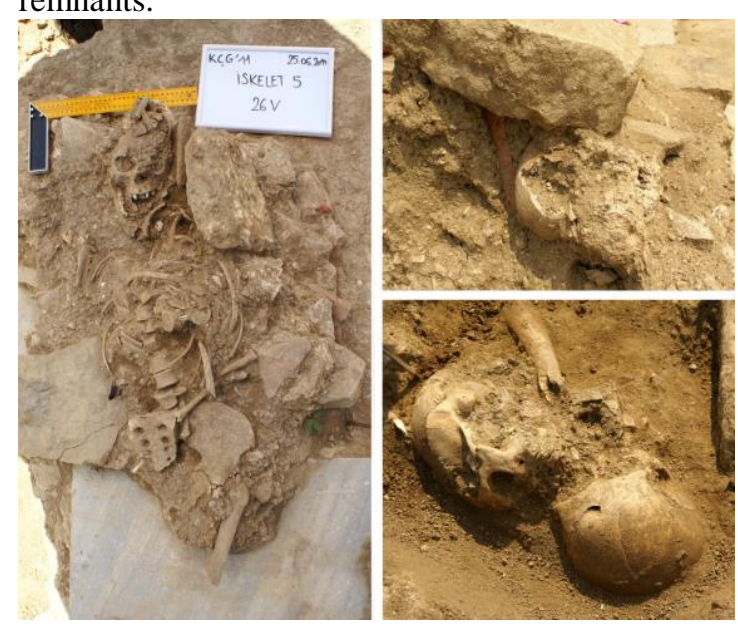

Fig. 4a-b-c. Excavations of skeletons obtained on the marble floor of the church, individuals holding each other crushed under the collapsed semi-dome.

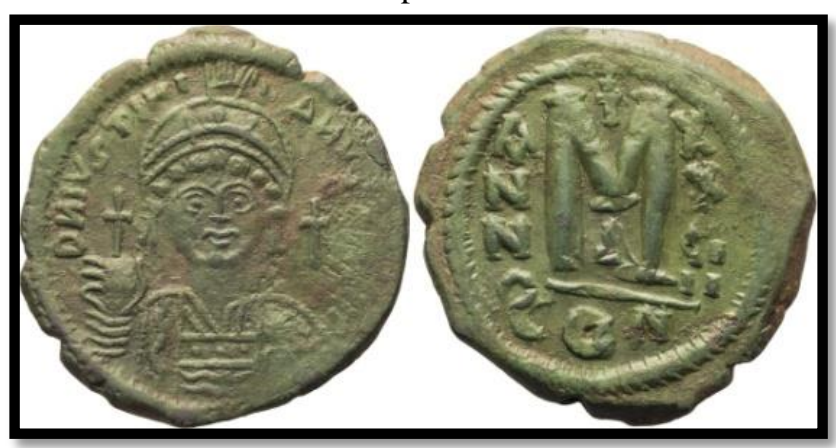

Fig. 5. Emperor Justinian coin found near individuals under the collapsed semi-dome and dated to 550 .
These skeletons were found on a marble floor and among stones and soil remains forming different layers, with fractures not only identified in their skulls but in arm, leg and rib bones (Figure 4a-c). Other evidence that this destruction and death occurred after a disaster like an earthquake is that these individuals were not buried in the city's necropolis. The individuals were found on the marble floor of the church under stones and rubble. According to forensic medicine expert Dr. Ömer Turan on the excavation science team, the skulls of the individuals were broken by heavy architectural stone fragments and one of the most important pieces of evidence documenting that death occurred due to remaining under destruction due to shaking was that stone fragments were found within the fractures in the skull. This evidence is shown in Figure 4a, b, c.

In addition to the bones of individuals under the rubble, coins obtained belong to Justinian I (527-565) who was emperor in the $6^{\text {th }}$ century. The coins found under this collapsed structure were determined to date from 550 according to the excavation numismatic and ancient historian (Figure 5).

A tunnel noticed in the water infrastructure of the building was researched by our gallery cave group and it was identified that the tunnel narrowed to $20 \mathrm{~cm}$ at some points (Figure 6). It is thought that this narrowing is connected to the events which collapsed and destroyed the apse structure Eğilmez et al., 2017.

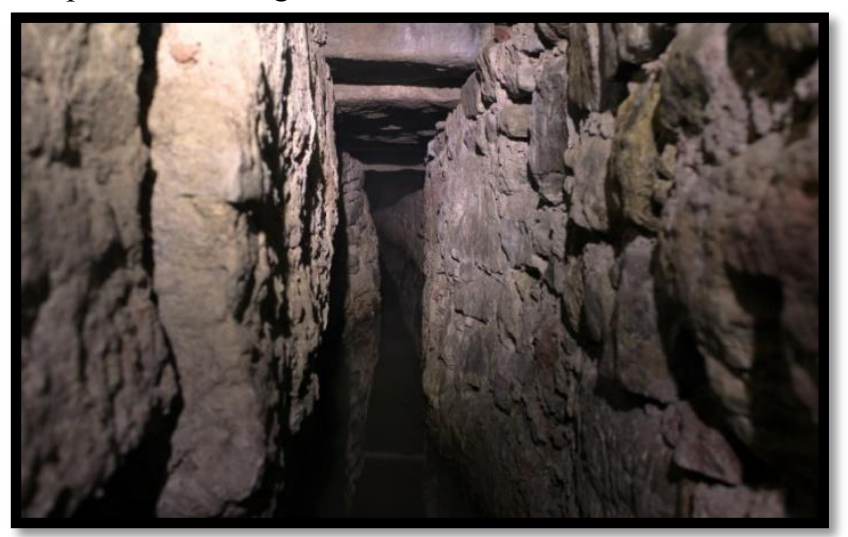

Fig. 6. Water tunnel with deformation after ground movements. The tunnel narrowed to $20 \mathrm{~cm}$ at some points.

\section{Archeological and Architectural Studies in the Great Cistern}

Excavations of Bathonea completed in Küçükçekmece Lake Basin identified traces of the same seismic movements in structures in the section defined as "inside the walls" in the northeast of the peninsula. Geophysical and surface research in areas 7 and 8 identified the presence of a large structure. According to the data, the structure revealed by excavations was given the name "Great Cistern". There is nearly $600 \mathrm{~m}$ distance between the church structure and the great water cistern.

Excavations in plan square 21-24 FL in Area 7 encountered a long body wall. Extending in northwestsoutheast direction, excavations discovered the presence of a rectangular-shaped cistern. The cistern excavations 
have not been fully completed, but two sections of the body walls may be investigated. With the aim of identifying the dimensions of the cistern, excavations following the walls measured $70.2 \mathrm{x} 18.2 \mathrm{~m}$. Investigations of the cistern identified that after destruction occurring in the Late Antique Period the standing body walls in north and west directions were preserved, while additions to the west wall were extended and a new wall was completed in the west section, indicating that perhaps the building continued to be used for a different function. The original structure had internal dimensions of $40 \times 13 \mathrm{~m}$ according to the plan scheme in its current form. The body walls with nearly $3 \mathrm{~m}$ thickness were made of brick and mortar on the interior, while the external surface displays stone and brick alternations. With brick thickness varying from 4-5 $\mathrm{cm}$, the structure has nearly $4 \mathrm{~cm}$-thick mortar. In terms of construction technique and material, the structure is dated to Late Roman-Early Byzantine period, and was organized with oval form at the corners of the walls to increase pressure resistance at the corner points, a specific design principle for body walls in contact with water. The internal surface of the body walls is covered with $5 \mathrm{~cm}$-thick red-colored hydraulic plaster. The floor of the cistern is covered with hydraulic plaster with 10 $\mathrm{cm}$ thickness. The presence of terracotta pipes inserted at regular intervals in the body walls of the cistern is remarkable as an exceptional application that is not found in Istanbul cisterns. Each has $20 \mathrm{~cm}$ diameter and $38 \mathrm{~cm}$ length, and it appears the back sections of the pipe were consciously closed (Figure 7).

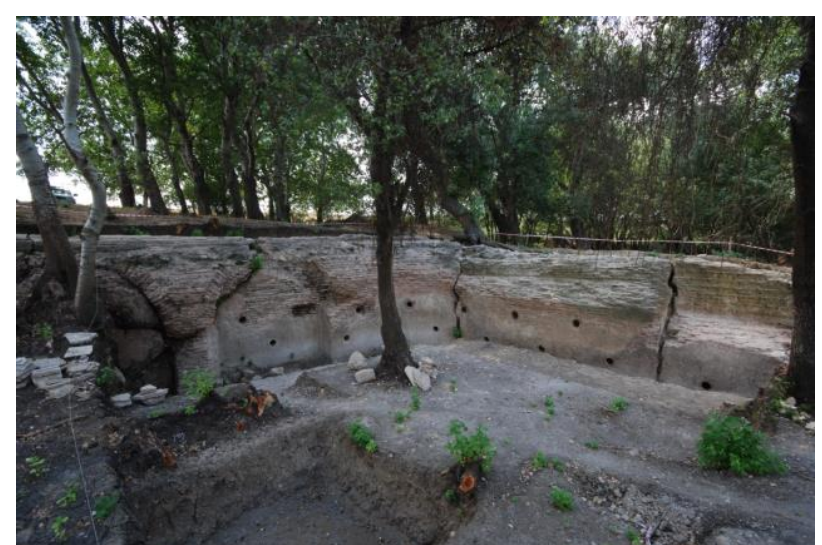

Fig.7. Body walls with oval corners in the cistern and offsets and damage identification relief studies of walls due to probable large earthquake.

First observations led to consideration that the pipes were inserted in the body walls as a precaution against pressure on the walls when large amounts of water were stored in the cistern (Altuğ, 2017: 181).

Field observations observed that some walls in the cistern were laterally collapsed. It is probable that this form of destruction of these types of strong walls may have occurred with force occurring during seismic motions. Detailed observations of the cistern continue, but though some walls were very thick, we identified that walls had fractured and were offset with the causes of this type of damage investigated. This damage strengthened our belief that it probably occurred due to destructive earthquakes affecting the region (Figure 8ab-c).
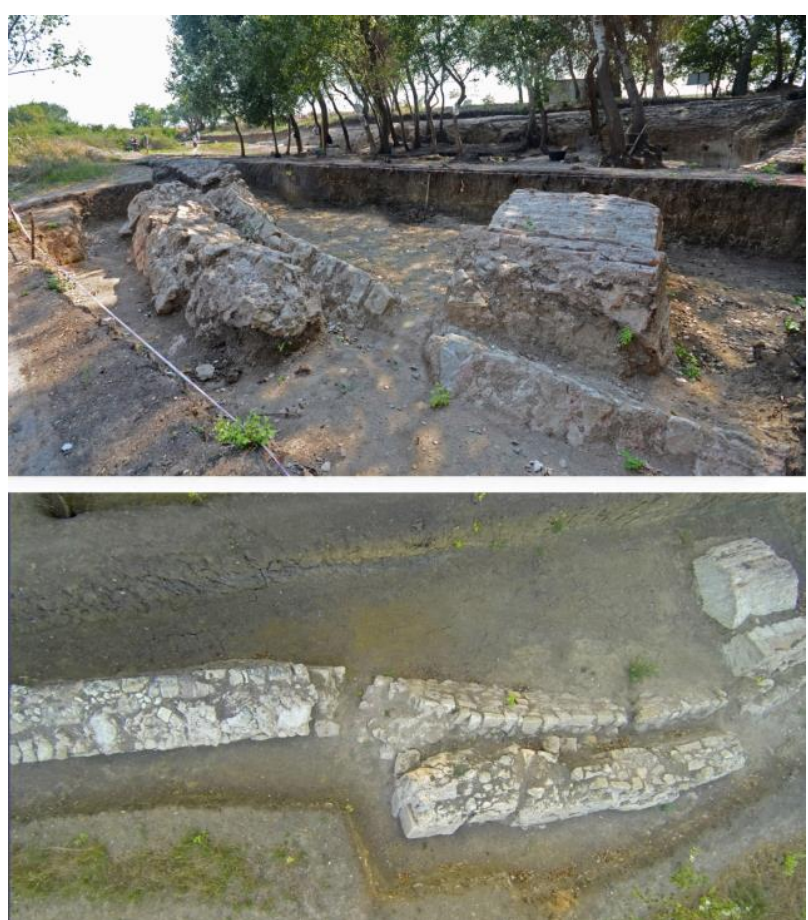

Fig. 8a-b. Laterally collapsed wall in the water structure due to probable earthquake effects.

According to results of technical investigation of the Great Cistern, nine arch traces were identified at threemeter intervals on the west side of the structure, and these are considered to indicate the joist points for arches carrying the roof system of the cistern. This result reveals that the structure may have been an enclosed cistern. With walls reaching $3 \mathrm{~m}$ thickness, this strong structure may represent the infrastructure of a significant building carried above it in the past. However, with incomplete excavation, the archeological fill remains within the cistern. From this aspect, drilling studies planned for the autumn of 2020 in fill within the cistern, along with georadar scanning; will provide more definite data in terms of explaining this problem. The results of studies of the Great Cistern identified in Küçükçekmece Lake Basin (Bathonea) excavations lead to consideration that the possible roof system of the cistern collapsed as a result of a probable earthquake in the Early Byzantine period and that construction material from the vaults were transported and used in other structures in the area (Altug 2017). In addition to indicators provided by the construction technique, stamped bricks obtained from the Great Cistern indicate that the construction of the structure began in the period of Emperor Constantine (324-337) and then continued later as understood from bricks carrying the stamps of Constantine and his consecutive sons Contans (337-350) and Constantius (337-361) (Aydıngün, 2013: 46-47; Sayar, 2015: 187-189).

Excavations in a structural complex from a later period located in trenches $12-17 \mathrm{EFG}$ in area 8 found stamped bricks in parallel with samples from the cistern and are considered to have been taken from part of the Great 
Cistern. The use of bricks as spolia material is not uncommon in the geography of the empire. Especially with the closure of marble quarries on Marmara Island from the $7^{\text {th }}$ century, new construction is known to have used spolia from abandoned structures destroyed by disasters like fires or earthquakes commonly in Istanbul and surroundings (Betsch, 1977: 35-42; Crow et al., 2008: 138; Altuğ 2012: 11; 2013: 66). We see that single load bearers and column headers probably from the cistern were used in structures in the $7^{\text {th }}$ and $8^{\text {th }}$ centuries in the area (Altuğ 2017: 182).

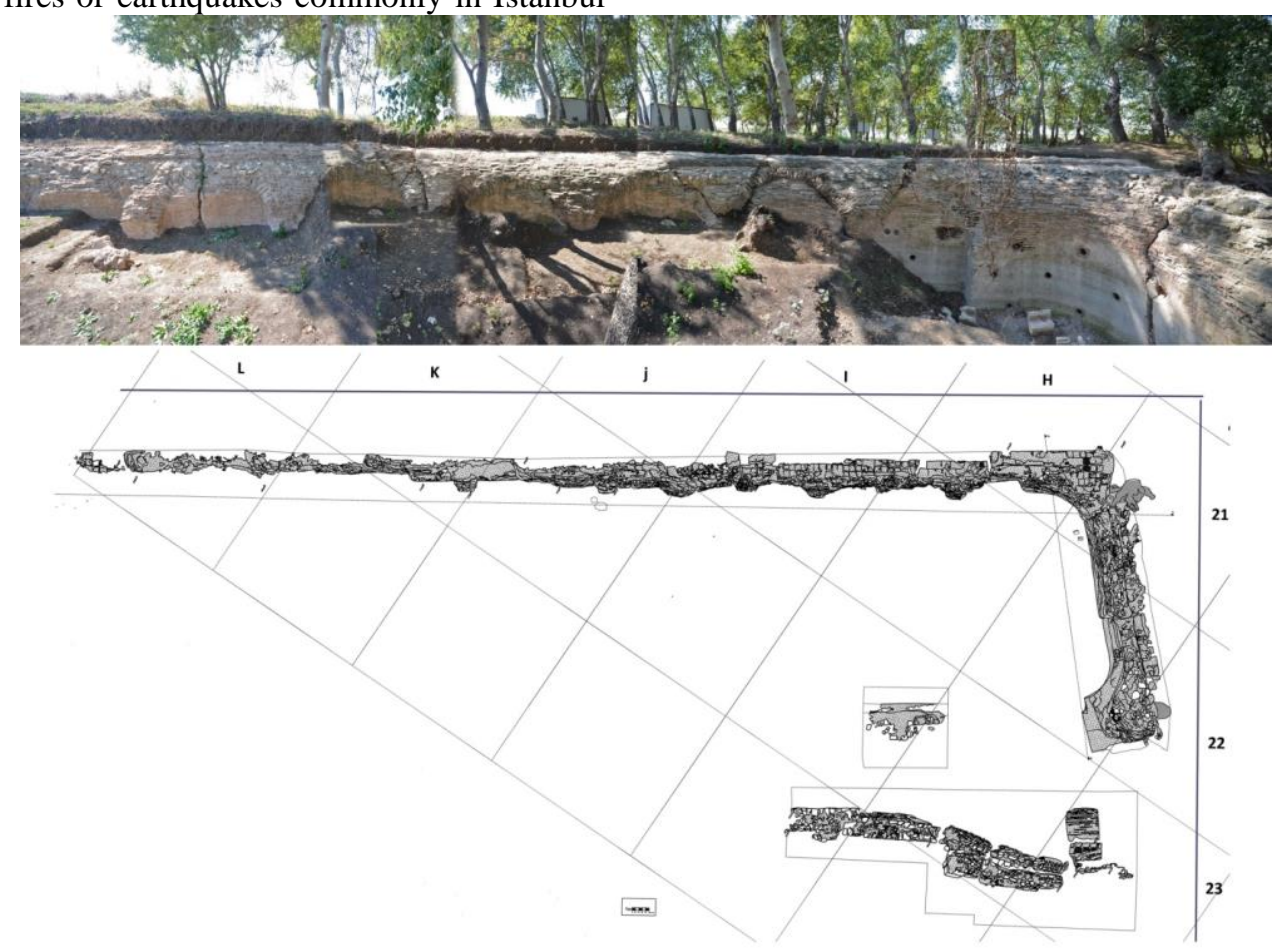

Fig. 8 c. General view of great cistern and plan.

The specific feeder channels for the cistern should be located in the upper levels of the body walls. However, there were no tunnel traces identified as required in the upper sections due to seismic movements occurring over time in these sections. At the south of the long wall, two tunnels connected with the cistern were identified and research began by the "Gallery Cave Group" (Kuruçayırlı et. al., 2015). Investigations within the tunnel noticed abnormal narrowing in some sections of the interior of the tunnel. This movement is thought to be associated with a seismic event, as in the tunnel close to the apse structure (Eğilmez et. al., 2017).

Apart from technical investigations of the structure, geophysical and seismic investigations identified probable wall offsets and some structural damage traces on observational measurements of the exposed cistern walls and in the cistern structures. Offsets in the cistern walls and fractures in the walls, especially, led to the view that they occurred as a result of large earthquakes occurring in the region. Some findings were obtained that are compatible with other observations in the region of the cistern. Similar damage and several skeletons give the impression that damage and loss of life occurred during a large earthquake within the settlement.

Constructed fully of stone and bricks, no carbon traces were encountered in the wall intervals. However, ceramic fragments obtained from the floor were mostly lamps dated to the $6^{\text {th }}$ century. According to initial assessments based on findings, damage to other buildings excavated to date and the walls of the cistern was concluded to have formed as a result of large earthquakes in the $6^{\text {th }}$ century, probably in the years 553553 and 557, and the strong aftershocks occurring after these earthquakes.

\section{Geophysical Studies}

Geophysical studies of the excavation site by scientists from Kocaeli and Kiel Universities ${ }^{2}$ used three methods of geomagnetic, geoelectric and georadar (Pekşen et al., 2017).

\section{Geomagnetic}

Geomagnetic field variations were measured with a Fluxgate gradient magnetometer. For this, 6 gradient sensors were mounted on a wheelbarrow made of material which would not disrupt the magnetic field at $50 \mathrm{~cm}$ intervals. Within each probe, two sensors were placed at a $60 \mathrm{~cm}$ interval in the vertical direction with one at the top and one at the bottom. These two sensors receive different measurement values. In the field, in line with advances of the magnetic sensor carrier, 6 magnetic profiles at $50 \mathrm{~cm}$ intervals were recorded with 20 values per second. The wheelbarrow was advanced with speed of nearly $0.6 \mathrm{~m} / \mathrm{s}$ and field coordinates were measured once per second with differential GPS (DGPS) and

\footnotetext{
${ }^{2}$ Geophysical studies completed by Dr. Harald Stumpel and Dr. Ercan Erkul from Kiel University headed by Prof. Dr. Şerif Barış from Kocaeli University .
} 
transferred to a laptop mounted on the wheelbarrow to check the coordinates and orientation for every point measured along the profile online.

\section{Geoelectric}

Geoelectric measurements were performed with a RESECSMulti-Electrode System. Profiles with length of $95 \mathrm{~m}$ were taken by driving electrodes into the group at 0.5 or $1 \mathrm{~m}$ intervals with measurements taken with dipole-dipole, Wenner and Schlumberger electrode arrays along the profile. Thus, the apparent resistivity of the location was calculated by the measurement device dependent on the measurement geometry and then true resistivity and depths were calculated with the RESINV2D (Loke, 2016) inversion analysis program.

\section{Georadar}

Georadar measurements were completed with a GSSISIR-20 device and $400 \mathrm{MHz}$ antenna. Coordinates of measurement profiles were recorded with the DGPS system and profiles were measured at $30 \mathrm{~cm}$ intervals. Radar grams were recorded every $2 \mathrm{~cm}$ within the profile. During analysis, velocity estimations were made along the 2-dimensional profiles and depths were calculated. Additionally, 2-dimensional profiles were combined to create 3 -dimensional time slices.

\section{Measurement Results}

Geomagnetic measurements could be taken over a total of 2 hectares in the region. The locations of the measurement sites are shown with red color in Figure 9 and Figure 10 show the geomagnetic measurements on a satellite map (Pekşen et. al., 2017).

\section{Discussion and Conclusion}

Excavations in Bathonea located west of Istanbul on the coast of the Sea of Marmara in Firuzköy peninsula in Küçükçekmece Lake Basin determined intense damage in many structures and studies were performed to determine whether damage formed due to destructive earthquakes occurring in the region or not. The structures with most pronounced intense damage were the "Apse Church" and "Great Cistern" and these form the basis of this article. In the first example, the identification of the collapsed semi-dome of the Apse Church and skeletons of two people holding each other beneath the collapsed dome stones are assessed as important data.

The surface the skeletons were found on was a marble floor. Heavy dome stones, soil and a rubble pile were found above them. The fracturing of the skeletons' skulls by dome fragments and very scattered distribution of other bones shows that this was not a normal death. Bones like the ribs, arm and legs of the individuals were crushed and contained fractures. The forensic medicine experts in the excavation stated that the crush may have been under a very sudden and intense collapse based on investigations of the bones. The scattered and fractured bones belonging to the head and body show that these individuals were within the building when it collapsed due to sudden-onset shaking and were caught under the destroyed structural stones before they could escape.
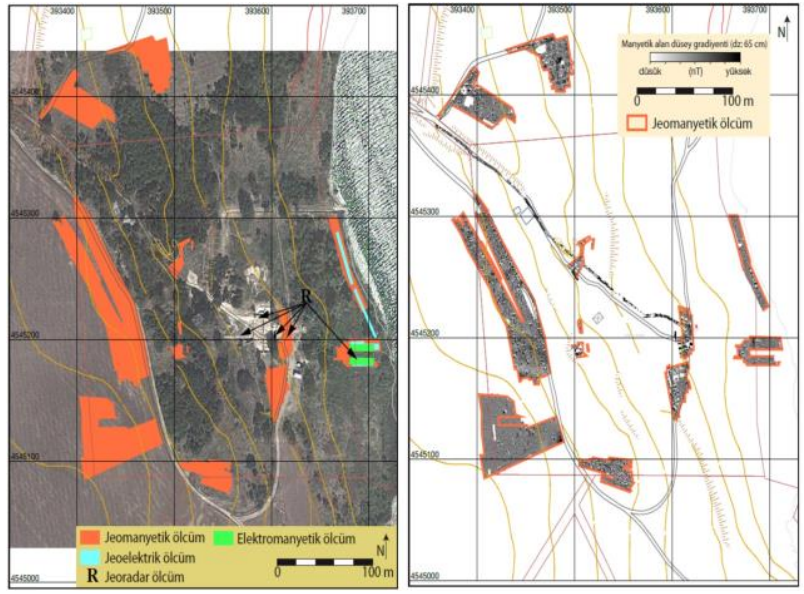

Fig. 9. Areas measured with geomagnetic method in the south section of the research area.

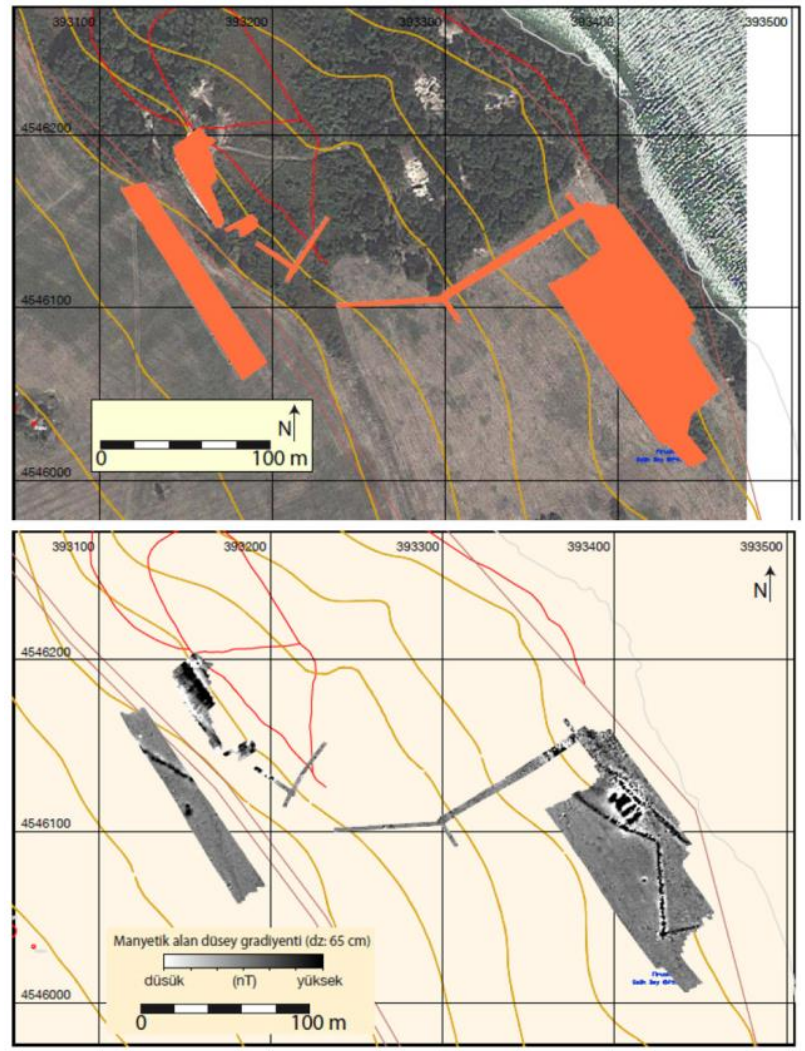

Fig. 10. Geophysical results from Great Cistern and surroundings. An example of the geomagnetic measurement results from the excavation area. Dark color regions show magnetic field variations. These probably show terracotta and rocks with magnetic characteristics.

Detailed research identified the presence of damage caused by earthquakes in different sections of the archeological site. When this damage is investigated, it was concluded that only strong earthquakes could cause damage like collapse of strong dome structures, wall coverings found on the floor of the church, wall collapses in other structures and breaking of marble columns. The next step after revealing that the town was destroyed by strong earthquakes was to determine the 
date of these earthquakes causing this damage by investigating historical catalogues, and comparing the findings with historical earthquakes. It is significant that a coin with Justinian's stamp dated 550 was found by careful excavation beside the individuals trapped under the dome. Additionally, ceramic fragments were also found and a perfume bottle dated to the $6^{\text {th }}$ century (Figure 11a-b). The clear date on the coin proves that these structures were destroyed by earthquakes occurring after 550. Similarly, the finding of skeletons under rubble, rather than in the city's necropolis, proves that death was sudden and that the structure was not used again as bodies were not removed from the rubble.
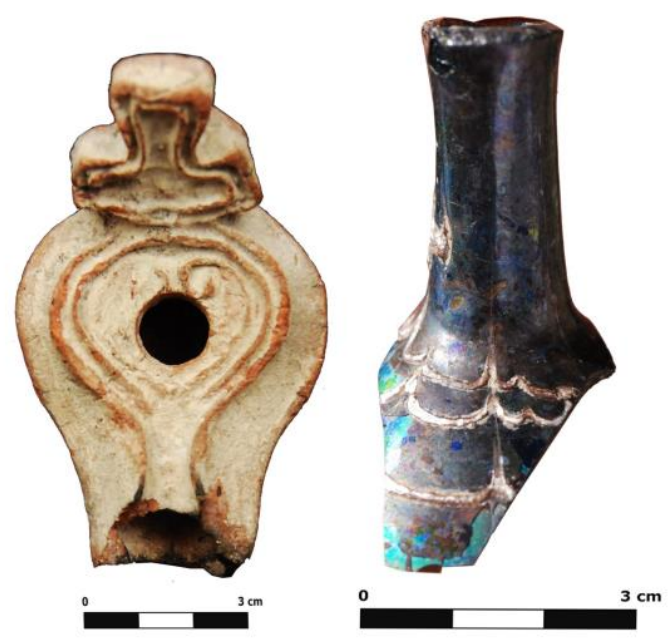

Fig. 11a-b. Oil lamp and a perfume bottle dated to the $6^{\text {th }}$ century

Similarly, nearly $600 \mathrm{~m}$ north of the church structure, visible offsets and collapsed walls in the Great Cistern are important. As a result, deformations, offsets and fractures observed in the cistern and in the tunnels providing water to the cistern prove earthquakes occurred in the $6^{\text {th }}$ century. Additionally, it was noticed that many different structures revealed in the excavation site were exposed to destruction due to earthquakes and it was understood that the effects of the earthquake spread over a large area. Archeological material obtained in excavations to be performed in the ancient Bathonea port settlement in future seasons and detailed geophysics and age dating will support these results and are expected to confirm some historical earthquakes mentioned by ancient and medieval writers that occurred in Istanbul with archeological evidence.

\section{Acknowledgemens}

This study is supported by Kocaeli University BAP project, Ministry of Culture and Tourism of the Republic of Turkey and General Directorate of Cultural Heritage and Museum. Besides, we thanks to Avcilar Municipality and Marport AŞ and special thanks to Eyüp Yildız, Erhan Bozan, Mehmet Aslan. We also thank to Prof. Dr. Ya Yazıcı Çakın, Dr. Ertan Peksen, Dr. İsmail Kaplanvural and students that participated in field survey of Kocaeli University, Department of Geophysics.

\section{References}

Afyoncu E (2018). Tarih Boyunca İstanbul Büyük Depremlerle Sars1ld1, Sabah Gazetesi, 23/09/2018 (in Turkish).

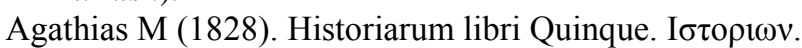
Bonnae: Impensis Ed. Weberi.

Agathias M (1878). V, 3; F. Unger, Quellen der byzantinischen Kunstgeschichte, Wien, I, 113, nr. 240.

Altuğ K (2012). Planlama İlkeleri ve Yapım Teknikleri Açısından Tarihi Yarımada'daki Bizans Dönemi Sarnıçları. Restorasyon Konservasyon Çalışmaları Dergisi 15: 3-22 (in Turkish)

Altuğ K (2013). İstanbul'da Bizans Dönemi Sarnıçlarının Mimari Özellikleri ve Kentin Tarihsel Topografyasındaki Dağılımı. İstanbul Teknik Üniversitesi, Fen Bilimleri Enstitüsü, Yayımlanmamış DoktoraTezi, Istanbul (in Turkish).

Altuğ K (2017). Küçükçekmece Göl Havzası (Bathonea?) Kazıları Büyük Sarnıç. İstanbul Küçükçekmece Göl Havzası Kazıları (Bathonea), Ed. Ş.Aydıngün, Ístanbul Arkeoloji ve Sanat Yayınları, 181-191. (in Turkish).

Ambraseys N (2002). The seismic activity of the Marmara Sea Region over the last 2000 years. Bulletin of the Seismological Society of America, 92, 1, 1-18, doi:10.1785/0120000843.

Ambraseys N (2009). Earthquakes in the Mediterranean and Middle East: a multidisciplinary study of seismicity up to 1900. Cambridge University Press. $\begin{array}{llllll}I S B N & 978 & 0 & 521 & 87292 & \text { 8.doi:10.1017/ }\end{array}$ S0016756810000452

Ammianus Marcellinus (Rerum Gestarum, XXXI.11) Ammianus Marcellinus. With An English Translation. John C. Rolfe, Ph.D., Litt.D. Cambridge. Cambridge, Mass., Harvard University Press; London, William Heinemann, Ltd. 1935-1940.

Aydıngün Ş (2005). Tarih Boyunca Yaşanan Depremler Sonras1 Ayasofya Onarımları. Kocaeli Deprem Sempozyumu, 2005. (in Turkish).

Aydıngün Ş (2013). Küçükçekmece Gölü Havzası (Bathonea?) Kazılar1 2009-2012. Ístanbul Araştırmaları Yıllı̆̆ / Annual of Istanbul Studies 2: 41-53 (in Turkish).

Aydıngün Ş (2017). Nehir Göl Deniz Birleşiminde Bir Kazı Yeri (İlk Beş Yıllık Çalışma) / An Excavation Site at the Junction of River-Lake and Sea (Works of the First Five Years). İstanbul Küçükçekmece Göl Havzasl Kazllarl (Bathonea), Ed. Ş.Aydıngün, Istanbul: Arkeoloji ve Sanat Yayınlarl, 1-13.

Bardakçı M (2015). Yarın büyük felâketin yıl dönümü ve 250 senelik uğursuz periyodun da habercisidir, Habertürk, 16.08.2015.

Barış Ş (1995). Earthquake Prediction A long the North Anatolian Fault Zone by using Seismicity Patterns, PhD Thesis, Boğaziçi University, İstanbul, Turkey.

Barka A (1981). Seismo-tectonic Aspects of the North Anatolian Fault Zone. PhD. thesis, University of Bristol, England.

Başarır Baştürk N, Özel N M, Altınok Y, Duman T (2017).Türkiye ve Yakın Çevresi İçin Geliştirilmiş Tarihsel Dönem (MÖ 2000 - MS 1900) Deprem 
Kataloğu, MTA Yayınları, Özel yayın Serisi No: 34, Ankara (in Turkish).

Betsch W E (1977). The History, Production and Distribution of the Late Antique Capital in Constantinople.University of Pennsylvania, Department of the Art History, Doctoral Dissertation, Philadelphia.

Crow J, Bardill J, Bayliss R (2008). The Water Supply of Byzantine Constantinople, Journal of Roman Studies Monograph 11, London.

Downey G (1947). The composition of Procopius, De aedificiis. In Transactions and Proceedings of the American Philological Association. 171-183.

Durukal E, Erdik M, Kaya Y (2001). İstanbul'da Tarihi Yapılar ve Deprem Riski. İstanbul Bülten, TMMOB Inşaat Mühendisleri Odası İstanbul Şubesi Yayın Organı, Yıl: 12, Sayı 55, pp. 4-13 (in Turkish).

Eğilmez A H, Kuruçayırlı E, Aydıngün Ş, Albükrek M, Küçükali G (2017). Küçükçekmece Göl Havzası (Bathonea?) Kazıları Antik Çağ Su Temin Tünelleri. İstanbul Küçükçekmece Göl Havzası Kazıları (Bathonea), Ed. Ş. Aydıngün, İstanbul: Arkeoloji ve Sanat Yayınlart. 193-216 (in Turkish).

Emre Ö, Duman T Y, Özalp S, Elmacı H, Olgun Ş et. al., (2013). Türkiye Diri Fay Haritas1. Maden Tetkik ve Arama Genel Müdürlüğü Özel Sayı Serisi. AnkaraTürkiye (in Turkish).

Gazioğlu, C., Gökaşan, E., Algan, O. Yücel, Z. Y., Tok, B., Doğan, E., (2002). Morphologic features of the Marmara Sea from multi-beam data, Mar. Geol. 190(1-2): 397-420.

Gökaşan, E. Gazioğlu, C., Alpar, B.; Yücel, Z.Y.; Ersoy, Ş. Gündoğdu, O., Yaltirak, C. (2002). Evidences of NW extension of the North Anatolian Fault Zone in Marmara Sea; a new approach to the 17th August 1999 Marmara Sea earthquake. Geo-Marine Letters, 21(4): 183-199.

Gökaşan, E.; Ustaömer, T.; Gazioğlu, C.; Yücel, Z.Y.; Öztürk, K.; Tur, H.; Ecevitağlu, B., Tok, B. (2003). Morpho-tectonic evolution of the Marmara Sea inferred from multi-beam bathymetric and seismic data. Geo-Marine Letters, 23(1), 19-33.

Guidoboni E, Comastri A, Triana G (1994). Catalogue of Ancient Earthquakes in the Mediterranean Area upto the 10th Century. Istituto Nazionale di Geofisica, $p$. 504. ISBN 88-85213-06-5.

Hébert, H., Schindele, F., Altinok, Y., Alpar, B., Gazioglu, C. (2005). Tsunami hazard in the Marmara Sea (Turkey): a numerical approach to discuss active faulting and impact on the Istanbul coastal areas. Marine Geology, 215(1-2), 23-43.

Kartal F, Kadirioğlu F (2015). Kuzey Anadolu Fay Zonunun Kinematiği. 19. ATAG Calıștayl, Sakarya (in Turkish).

Kaya H., Ertek T.A., Yücel Z.Y., Gazioğlu C. (2002). Avcılar (İstanbul) kıyı kullanımı ve kıyı kullanımı üzerine 17 Ağustos 1999 depreminin etkileri. Türkiye'nin K1yı ve Deniz Alanları IV. Ulusal Konferans1 (5-8 Kasım 2002) Bildirileri, 491-501.

Kaya, H., Çalık, MM., Şehla, C., GAzioğlu, C., Delibay, A., Kimyonok, T. (2020). Kiy1 Kentlerinde Kültür Varlıkları ve Jeoarkeoloji Çalışmaları (Beylikdüzü
Örneği), Güncel Sosyal Bilimler Araştırmaları, 153169.

Ketin I (1948). Über die tektonisch-mechanischen Folgerungenaus den grossen anatolischen Erdbeben des letzten Dezenniums. Geol. Rund. 36: 77 - 83.

Kuruçayırlı E, Eğilmez A H, Küçükali G, Albukrek M, Uzel ve E A, et al (2015).Water Supply Tunnels of Istanbul Küçükçekmece Lake Basin (Bathonea), Hypogea 2015 - Proceedings of International Congress of Speleology, Artificial Cavitie. Italy, Rome. 114-120.

Loke, M.H (2016). Tutorial : 2-D and 3-D electrical imaging surveys

Öniz, H., Kaya, H., Gazioğlu, C. (2015). Geoarchaeological Researches on the Mediterranean Coast, II. Klyı ve Deniz Jeolojisi Sempozyumu, 133p.

Öztürk Y K (2019). Dynamic Earthquake Rupture Simulations in the Sea of Marmara. PhD Thesis, Boğaziçi University, Istanbul, Turkey.

Pekşen E, Kapanvural İ, Barış Ş, Yas T, Livaoğlu H (2017). Avcılar-Firuzköy Yarımadası 1. Derece Arkeolojik Sit Alanında Yapılan Jeofizik Araştırmalar.İstanbul Küçükçekmece Göl Havzası Kazıları (Bathonea), Ed. Ş. Aydingün, Istanbul:Arkeoloji ve Sanat Yayınlarl, pp. 119-124 (in Turkish).

Sayar M H (2015). Ziegelstempelvon den Ausgrabungen am Nordwestuferdes Lagunensees Küçükçekmece. Inscriptions in Byzantium and Beyond MethodsProjects-Case Studies. Verlag der Österreichischen Akademie der Wissenschaften, ÖAW, 187-194.

Şengör A M C (1979). The North Anatolian Transform Fault: its age, offset and tectonic Significance. London: J. Geol. Soc. 136: 269- 82.

Sezer L İ (2003). 'İstanbul Yöresinde Deprem Aktivitesi ve Riski’. Sırrı Erinç Sempozyumu 2003 Coğrafya. 11-13 Eylül 2003 Genişletilmiş Bildiri Özetleri. Ístanbul Üniversitesi Edebiyat Fakültesi Coğrafya Bölümü ve Ístanbul Üniversitesi Deniz Bilimleri ve İşletmeciliği Enstitüsü Yayınlarl, 135-142, İstanbul. (in Turkish)

Soysal H, Sipahioğlu S, Kolçak D, Altınok Y (1981). Türkiye ve Çevresinin Tarihsel Deprem Katalogu (M.Ö. 2100-M.S.1900). TÜBITAK, Proje No: TBAG - 341 (in Turkish).

Tan O, Tapırdamaz M C, Yörük A (2008). The Earthquake Catalogues for Turkey, Turkish Journal of Earth Sciences, Vol. 17, pp. 405-418.

Turtledove H (1982).The Chronicle of Theophanes: an English Translation of Anni Mundi 6095-6305 (AD 602-813). University of Pennsylvania Press, 1982.

URL 1. https://deprem.afad.gov.tr/depremkatalogu; http://www.koeri.boun.edu.tr/sismo/2/deprembilgileri/buyuk-depremler).

URL 2. https://deprem.afad.gov.tr/depremkatalogu (01.012021)

USGS. (2020). The Modified Mercalli Intensity Scal, www.usgs.gov

Yaltırak C (2015). Marmara Denizi ve Çevresinde Tarihsel Depremlerin yerleri ve Anlamı, ITÜ Vakfi Dergisi, Sayı 67, pp. 51-58. 